\title{
One Market or Many? Labor Market Integration in the Late Nineteenth- Century United States
}

\author{
JoshuA L. RosenbloOM
}

This article examines the geographic integration of U.S. labor markets from 1870 to 1898 , using previously unexploited wage and price data for 23 occupations in 12 major cities. In contrast to the increasing nationalization found in other markets at that time, the labor market was characterized by large and persistent real wage differentials both within and between regions, leaving little doubt that late nineteenth-century labor markets remained far from completely integrated. The differentials, however, owed as much to substantial variations in labor demand growth as to the lack of labor market integration.

The late nineteenth century has often been regarded as the era in 1 which a national economy first emerged in the United States. By 1869 transcontinental telegraph and railroad lines had been completed, and the elaboration of national rail and telegraph networks over the next 30 years reduced the costs and increased the speed of transportation and communication. Responding to the opportunities that these technologies created, manufacturers in a wide range of industries consolidated markets for their products and introduced new, capital-intensive methods of production made possible by the larger geographic scope of markets. At the same time, various innovative financial institutions were promoting the interregional mobilization of both short- and longterm capital. While the proliferation of banks helped to break down local monopoly power, the advent of commercial paper houses, insurance companies, and national stock and bond exchanges promoted the mobilization of capital from surplus to deficit savings regions. ${ }^{1}$

In contrast to the attention that late nineteenth-century financial and product market integration has attracted, the emergence of a U.S.

The Journal of Economic History, Vol. L, No. 1 (Mar. 1990). (C) The Economic History Association. All rights reserved. ISSN 0022-0507.

The author is Assistant Professor of Economics, University of Kansas, Lawrence, KS 66045.

I am grateful to Paul David, Gavin Wright, and John Pencavel for their extensive comments. I would also like to thank Gregory Clark, Shane Greenstein, and two anonymous referees for many helpful suggestions.

${ }^{1}$ For a general discussion of the formation of a national economy, see Harvey S. Perloff, et al., Regions, Resources and Economic Growth (Lincoln, NE, 1965), pp. 191-221. The emergence of big business and its lasting impact on the American economy is traced in Alfred D. Chandler, Jr., The Visible Hand: The Managerial Revolution in American Business (Cambridge, MA, 1977); see also Richard B. Duboff, "The Telegraph and the Structure of Markets in the United States, 1845-1890," Research in Economic History, vol. 8 (Greenwich, CT, 1983), pp. 253-77. On the emergence of a national capital market, see, for example, John A. James, Money and Capital Markets in Postbellum America (Princeton, 1978). 
national labor market in this period has been largely neglected by economic historians, and what work has been done on labor market integration presents a confusing picture. While several studies have found evidence of a long-run tendency toward increasing integration, others indicate that the advance toward more efficient labor markets has not proceeded smoothly at all times or in all places. Stanley Lebergott and Richard Easterlin have found evidence of a long-run convergence in wages and earnings since the mid-nineteenth century, and a number of recent articles have concluded that labor market integration was increasing in the antebellum period as well. ${ }^{2}$ On the other hand, the persistence of a large North-South wage differential during much of the twentieth century has been interpreted as a lack of labor market integration between these regions. ${ }^{3}$ Similarly, several studies of late nineteenth-century wage data reveal the presence of persistent interregional differentials. ${ }^{4}$

In this article I present further evidence of the persistence of large geographic differentials in wage rates during the late nineteenth century. I show that although real wage rates in San Francisco converged toward eastern levels, large wage differentials persisted within as well as between the other regions of the country, with no trend toward convergence. Midwestern wages remained 20 to 25 percent higher than eastern wages-or about three to five times the magnitude of interregional differentials in the twentieth century - and differentials of 10 to 20 percent persisted between cities within the two regions. Closer examination suggests that these differentials owed as much to the substantial variation in rates of labor demand growth as to the lack of labor market integration.

\footnotetext{
${ }^{2}$ Stanley Lebergott, Manpower in Economic Growth: The American Record Since 1800 (New York, 1964), pp. 239-40; Richard A. Easterlin, "Interregional Differences in Per Capita Income, Population, and Total Income, 1840-1950," in Trends in the American Economy in the Nineteenth Century, National Bureau of Economic Research, Studies in Income and Wealth, vol. 24 (Princeton, 1960), pp. 91-92. The antebellum labor market is discussed in Robert A. Margo and Georgia C. Villaflor, "The Growth of Wages in Antebellum America: New Evidence," this JourNAL, 47 (Dec. 1987), pp. 873-95; and W.inifred B. Rothenberg, "The Emergence of Farm Labor Markets and the Transformation of the Rural Economy: Massachusetts, 1750-1855," this JoURNAL, 48 (Sept. 1988), pp. 537-66.

${ }^{3}$ Gavin Wright, "The Economic Revolution in the American South," Journal of Economic Perspectives, 1 (Summer 1987), pp. 161-78.

${ }^{4}$ Clarence D. Long, Wages and Earnings in the United States, 1860-1890, National Bureau of Economic Research, General Series, no. 67 (Princeton, 1960), finds large interregional differentials in nominal wages from 1860 to 1890 with wages highest in the Midwest, lowest in the South, and intermediate in the East. Philip R. P. Coelho and James F. Shepherd, "Regional Differences in Real Wages: The United States, 1851-1880," Explorations in Economic History, 13 (Apr. 1976), pp. 203-30; and Philip R. P. Coelho and James F. Shepherd, "The Impact of Regional Differences in Prices and Wages on Economic Growth: The United States in 1890," this Journal, 39 (Mar. 1979), pp. 69-85, report that adjusting nominal wages for differences in the cost of living across regions increases, rather than decreases, these wage differentials.
} 


\section{LABOR MARKET INTEGRATION AND WAGE BEHAVIOR}

As geographically distinct markets become increasingly integrated, there should be a narrowing of differences in price levels. ${ }^{5}$ Within a completely integrated labor market, workers at every location are aware of all employment opportunities elsewhere and through migration can offer their services to employers anywhere. As a result, the labor force at each location will adjust to equate the level of utility which may be achieved by a representative worker. If there are no site-specific amenities or disamenities, this adjustment will also result in the equalization of real wages for workers of equal ability doing identical work. In the presence of amenities, however, migration will cease when real wage differences just compensate individuals in each location for the variations in these amenities. ${ }^{6}$

Complete integration is unlikely to be observed in most real markets, and the empirical problem is that of determining the relative divergence of the observed situation from complete integration. Because potential migrants must bear the cost of acquiring information about employment opportunities at distant locations as well as the expense of transportation to get there, they will migrate only if the real wage differential exceeds these combined "costs of movement." Consequently, real wages may vary between locations but by no more than the cost of movement faced by the marginal migrant. The size of the real wage

${ }^{5}$ This is the criterion that has been used most often in historical studies of capital market integration. See, for example, Lance E. Davis, "The Investment Market, 1870-1914: The Evolution of a National Market," this Journal, 25 (Sept. 1965), pp. 355-99; Gene Smiley, "Interest Rate Movements in the United States, 1888-1913," this Journal, 35 (Sept. 1975), pp. 590-620; and John A. James, "The Development of a National Money Market," this Journal, 36 (Dec. 1976), pp. 878-97. Recently, several articles in the antitrust literature have proposed that the extent of the market be measured by the similarity of price movements. George J. Stigler and Robert A. Sherwin, "The Extent of the Market," Journal of Law and Economics, 28 (Oct. 1985), pp. 555-85; and Pablo T. Spiller and Cliff J. Huang, "On the Extent of the Market: Wholesale Gasoline in the Northeastern United States," Journal of Industrial Economics, 35 (Dec. 1986), pp. 131-45. Kerry A. Odell, "The Integration of Regional and Interregional Capital Markets: Evidence from the Pacific Coast, 1883-1913," this JouRnal, 49 (June 1989), pp. 297-310, suggests a method for combining these two criteria. While it is not practical to extend Odell's method to an examination of 12 distinct locations, the correlation of wage movements across cities largely confirms conclusions drawn on the basis of the pattern of intercity variation in wage levels. Joshua L. Rosenbloom, "Labor Market Institutions and the Geographic Integration of Labor Markets in the Late Nineteenth Century United States" (Ph.D. diss., Stanford University, 1988).

6 The preceding discussion assumes that the location of "employers"- -or more properly the other factors of production-are fixed. If the relocation of these other factors of production is taken into account, then the effect on wages of any site-specific amenities will eventually be eliminated since, unlike owners of labor services, the owners of these other factors of production do not have to move with these factors, and their location decisions will not be affected by the presence of amenities. Complete spatial equilibrium will be achieved only when all factor prices and utility levels are equalized. In the case where there are site-specific amenities this can occur either through the concentration of all workers and "employers" in one place (the site with the most favorable amenities) or through the dissipation of these amenities as the result of increased congestion at physically constrained locations. 
differential may thus be used to measure the information and transportation costs preventing complete integration. ${ }^{7}$ While the direct costs of transportation at any point in time reflect the resource costs of transferring labor from one place to another, the remainder of the differential reflects the costs of communicating labor market information and is thus a measure of the institutionally determined transactions cost preventing greater arbitrage.

\section{WAGE AND PRICE DATA}

In this article I consider daily wage rates for 23 occupations in 12 cities from 1870 to $1898 .^{8}$ This major collection of wage data provides the only annual coverage of a consistent sample of occupations and locations from 1870 until the end of the century. ${ }^{9}$ In each city the wage quotations for each occupation were collected by the U.S. Department of Labor from the payroll records of at least two establishments that had "existed and done business continuously since 1870 . . .." Wages were not collected for every occupation in each city, but, where collected, they were reported for each year from 1870 to 1898 . Data were collected for each individual employed by these establishments, but only the average wage for all individuals in a given city and occupation was reported. ${ }^{10}$ The department's purpose in collecting the data was comparative, and the occupations included in the study were chosen because they were "susceptible to accurate definition."

Although neither the occupational nor geographic coverage can be considered representative of the economy as a whole, a wide range of

\footnotetext{
${ }^{7}$ Two problems make it difficult to infer the extent of labor market integration from the behavior of wages. First, measurement problems make it difficult to detect integration where it does exist. Heterogeneity in the workers' ability, the kind of work they are doing, the other conditions of employment, or the presence of site-specific amenities will distort the measurement of labor market integration since we are no longer comparing the prices of identical commodities. As a result, observed wages may differ across locations even in a completely integrated labor market. Second, the integration of markets for finished products and/or other factors of production will tend to equalize wages even if labor is completely immobile, creating the appearance of labor market integration even where it does not exist. Paul A. Samuelson, "Prices of Factors and Goods in General Equilibrium," Review of Economic Studies, 21 (1953-1954), pp. 1-21; and Robert A. Mundell, "International Trade and Factor Mobility," American Economic Review, 47 (June 1957), pp. 321-35. While the similarity of wage differentials in industries in which product market arbitrage is possible, such as the metal-working trades, with those in local market industries, such as construction, indicates that product market integration was not a significant influence on local wage rates, problems of measurement are more difficult to rule out, and their possible effects on wages are considered in more detail in Section IV.

8 The data come from U.S. Department of Labor, "Wages in the United States and Europe, 1870-1898," Bulletin of the Department of Labor, no. 18 (Sept. 1898), pp. 665-93.

9 The principal sources of wage data in the late nineteenth century are discussed in Long, Wages and Earnings, pp. 13-17.

${ }^{10}$ U.S. Dept. of Labor, "Wages in the United States and Europe," pp. 665-66. Correspondence with the historian of the department and with the staff of the National Archives uncovered no other records relating to this study and no trace of the more than 400 pages of underlying individual wage quotations to which the study refers.
} 
activities and skill levels were included, and there is at least one city from each major region. The greatest number of occupations is in the construction and metal-working trades. ${ }^{11}$ The geographic coverage is concentrated in the Northeast and Midwest, with 9 of the 12 cities in these two regions. ${ }^{12}$ Nonetheless, one western city-San Franciscoand two southern cities-New Orleans and Richmond-are also represented.

The wage data are in nominal terms and must be adjusted for the relatively large geographic variations in the cost of living that prevailed during the late nineteenth century. ${ }^{13}$ In order to examine real wages I constructed retail price indices for each of the 12 cities. Because of the limited availability of the requisite geographically disaggregated price data, the coverage was restricted to retail food prices in three years: 1869,1890 , and $1898 .{ }^{14}$ Despite this limited coverage the resulting indices are still quite useful. The proportion of family budgets devoted to food remained by far the largest component of expenditures in working-class budgets-accounting for 56 percent of expenditures in 1875 and 41 percent in $1890 .{ }^{15}$ Moreover, because retail margins are

${ }^{11}$ The occupations covered by the data are blacksmiths, boilermakers, iron molders, machinists. pattern makers, blacksmiths' helpers, boilermakers' helpers, iron molders' helpers, machinists' helpers, bricklayers, carpenters, stone masons, house painters, plumbers, hod carriers, common laborers, street laborers, teamsters, cabinet makers, compositors, railroad firemen, joiners, and stone cutters. While the coverage of the data is tilted toward craft workers and away from industrial employees, the occupations included nonetheless represent a considerable fraction of the urbatn manufacturing labor force.

${ }^{12}$ The northeastern cities are Boston, New York, Philadelphia, Baltimore, and Pittsburgh. The midwestern cities are Cincinnati, Chicago, St. Louis, and St. Paul.

${ }^{13}$ Philip R. P. Coelho and James F. Shepherd, "Differences in Regional Prices: "The Inited States, 1851-1880," this Journal, 34 (Sept. 1974), pp. 551-91; Coelho and Shepherd, "I "The Imparct of Regional Differences"; and Michael R. Haines, "A State and Local Consumer Price Index for the United States in 1890," Historical Methods, 22 (Summer 1989). Unfortunately, the regional price indices constructed by Coelho and Shepherd are not sufficiently geographically disatggregited to be of direct use in examining intercity variations in retail prices. Haines reports price indices fors individual cities, but his work became available too late to be employed in this study. Although the price indices I report later are based on a more restricted set of items than are those construeted by Haines, they appear quite similar for the 12 cities considered here, and no substantive changes would result from using Haines's estimates of the cost of living.

${ }^{14}$ Even so, for the beginning of the period it is necessary to settle for data at the state level. The data for 1869 are reported in U.S. Treasury Department, Bureau of Statistics, The Cost of L.tab*:F and Subsistence in the United States in the Year 1869, by Edward Young (Washington, DC, 18701 . Prices were collected in the "towns" in each state. Although there is some basis for concern abaut how accurately prices in these towns will reflect prices in the large cities being examined herc. Coelho and Shepherd, "The Impact of Regional Differences," pp. 80-81, find that in 1890 there $w_{\text {ans }}$ no correlation between city size and the level of urban prices. Their price index does not include housing costs, but neither does the price index employed in this article. Prices for every yciar between 1890 and 1898 are reported in U.S. Department of Commerce and Labor, Eighte "enth Annual Report of the Commissioner of Labor, 1903: Cost of Living and Retail Prices of Fopul (Washington, DC, 1904).

${ }^{15}$ The results of late nineteenth-century expenditure surveys are summarized in Coelho and Shepherd, "Differences in Regional Prices," pp. 563-64. Their work also provides some indication of how accurately variations in retail food prices are likely to reflect variations in the prices of other 
likely to depend upon such costs of doing business as site rent, they will reflect, at least partially, variations in other components of expenditures. ${ }^{16}$ Thus, retail food prices should be a good proxy for the overall cost of living. Meanwhile, in view of the stability of relative price differentials revealed in both the data employed here and that discussed by Philip Coelho and James Shepherd the chronological restrictions do not appear to be a significant obstacle to comparisons of relative real wage levels.

Table 1 reports my estimates of relative retail food prices in each city for 1869,1890 , and 1898 . In each year prices are expressed relative to the average across all 12 cities. On the whole these estimates conform to the pattern of variation found in previous studies: prices were highest in New England and the Middle Atlantic regions and markedly lower in the Midwest. Prices on the West Coast were above average but not appreciably above those in eastern cities. The two southern cities present a somewhat divergent picture, but it would appear that prices were only slightly below average in Richmond and New Orleans.

\section{INTERCITY VARIATION IN REAL WAGES}

The wage rate for any occupation reflects a variety of different influences. While wages vary from occupation to occupation because of human capital requirements or other characteristics specific to the occupation, wages vary from place to place because of intercity differences in the relative supply of and demand for labor of a particular type. It is these latter, geographic differences, which reflect the extent of labor market integration.

To measure the effects of labor market conditions on wages in each city-and hence the extent of labor market integration-requires some assumption about the way in which occupation and location influence wages. Adopting a linear in logarithms specification, the natural logarithm of wages in occupation $i$ and city $j$ may be expressed as

$$
\ln \left(W_{i j}\right)=\rho_{i}+\pi_{j}+\varepsilon_{i j}
$$

components of expenditures. They calculated both an overall price index for each region and subindices for food, rent, clothing, and fuel and light. Some differences are apparent in the behavior of the subindices, but retail food prices do a fairly good job of measuring the overall level of retail prices.

${ }^{16}$ The role of retail margins seems particularly important in accounting for the fact that retail prices varied considerably more between cities than did wholesale prices. Data collected by the Department of Agriculture indicate that wholesale prices of pork and wheat varied by only 2 or 3 percentage points between Chicago, St. Louis, and Cincinnati, while wholesale prices in these cities generally remained within 5 to 10 percentage points of those in New York, a much smaller variation than is revealed by the retail price data discussed later. U.S. Department of Agriculture, Report of the Commissioner of Agriculture, 1881 and 1882 (Washington, DC, 1882), pp. 654-61; and U.S. Department of Agriculture, Report of the Secretary of Agriculture, 1890 (Washington, DC, 1890), pp. 322-323. 
TABLE 1

RELATIVE RETAIL FOOD PRICES IN SELECTED CITIES

\begin{tabular}{lrrr}
\hline \hline \multicolumn{1}{c}{ City } & 1869 & 1890 & 1898 \\
\hline Northeast & & & \\
$\quad$ Boston & 119.3 & 105.9 & 115.1 \\
New York & 104.4 & 113.6 & 111.1 \\
Philadelphia & 101.3 & 114.6 & 109.3 \\
Baltimore & 110.5 & 99.2 & 102.0 \\
Pittsburgh & 101.3 & 100.6 & 99.0 \\
Midwest & & & 96.8 \\
Cincinnati & 84.5 & 98.2 & 84.8 \\
Chicago & 86.8 & 92.5 & 91.2 \\
St. Louis & 89.8 & 86.7 & 85.2 \\
St. Paul & 81.8 & 87.3 & 108.2 \\
West & & & 99.3 \\
San Francisco & 107.7 & 114.1 & 100.5 \\
South & & 90.3 & \\
Richmond & 95.7 & 97.0 & \\
New Orleans & 118.2 & & \\
\hline
\end{tabular}

Note: Average across all cities equals 100 in each year.

Source: See the Appendix for a description of the construction of the price indices and their coverage.

where $\rho_{i}$ represents the effects of factors common to occupation $i$ in all cities, $\pi_{j}$ represents the effects of factors common to all occupations in city $j$, and $\varepsilon_{i j}$ is a residual representing the effects of factors specific to occupation $i$ in city $j .{ }^{17}$ Regressing the log of wages on a set of dummy variables for each city and occupation, $\rho_{i}$ and $\pi_{j}$ are measured by the coefficient on the relevant occupation and city dummy variables. ${ }^{18}$ In effect this is an analysis of variance regression with no interaction. The parameter estimate $\pi_{j}$-hereafter called the "city effect"-measures the effect of general labor market conditions on wages, while the regression residual, $\varepsilon_{i j}$, measures the deviation of wages caused by local labor market conditions specific to the individual occupations. ${ }^{19}$ Esti-

${ }^{17}$ The choice of a linear in logarithms decomposition is suggested by the a priori expectation that the costs of movement which the city effect is intended to measure are likely to be proportional to wages. Such a specification may be rationalized under the assumption that the primary costs of movement involve the expense of information gathering and hence will reflect the opportunity cost of time spent in other employment. If the true relationship takes some other form, then this specification may be regarded as a first order approximation to the true relationship. One alternative is the assumption that migrants in all occupations face an identical fixed cost of movement-such as would be the case if transportation costs were the major barriers to labor market integration. In this case an additive specification would make more sense. In practice the results reported below are insensitive to the choice between these two specifications.

${ }^{18}$ Alternatively, intercity wage differentials could be computed using the average wage in each city. However, because the occupational coverage of the data varies from city to city, average wages will confound the effects of these occupational differences with the spatial variations which we seek to measure. In contrast, the regression approach employed here corrects for these occupational differences.

19 If $\varepsilon_{i j}$ is assumed to be distributed normally, it is possible to test hypotheses about the statistical significance of differences in the magnitude of the coefficients estimated by the regression. It may 
mates of regional effects on wages can be obtained in much the same manner by replacing individual city dummy variables with a set of regional dummy variables. In practice, the regression is most easily estimated by normalizing wages relative to a single city and occupation. The level of wages in this "excluded category" is estimated as the intercept in the regression, and the other parameter estimates constitute the incremental effect of being in any other city and/or occupation. ${ }^{20}$

Tables 2 and 3 report relative nominal and real wages by cities and regions for five-year intervals from 1870 to $1898 .^{21}$ The base for intercity comparisons is New York, that for interregional comparisons is the Northeast region. In all cases the excluded occupation is street laborers. Looking first at the behavior of nominal wages, with the exception of the precipitous decline of wages in San Francisco, relative wage levels were quite stable over time. In addition, a rough equalization of nominal wages prevailed across most of the cities. Richmond, in the South, and San Francisco, in the West, diverged appreciably from the levels in other cities, but wages elsewhere were closely grouped. After San Francisco, New York and Chicago had the highest wages. In three other cities-Boston, Cincinnati, and New Orleans-wages began in 1870 to 1874 at roughly the same level as New York but had fallen below by the mid-1880s. This decline resulted in the convergence of nominal wage rates in most of the cities at a level between 85 and 90 percent of those in New York. Only in Chicago were wages close to those in New York.

be, however, that disturbances are correlated across closely related occupations with a particular city. If so, then we would expect to find that the estimated city effects varied systematically between occupation groups. This possibility will be taken up later.

${ }^{20}$ Defining the dummy variable $\delta_{k s}(k=i, j)$ such that $\delta_{k s}=1$ if $k=s$, and $\delta_{k s}=0$ otherwise, the regression equation can be written as

$$
\ln \left(W_{i j t}\right)=\alpha_{t}+\sum_{r=2}^{23} \rho_{r t} \delta_{i r t}+\sum_{s=2}^{12} \pi_{s t} \delta_{i s t}+\varepsilon_{i j t}, i=1, \ldots, 23 ; j=1, \ldots, 12
$$

where $i$ represents occupations, $j$ represents cities, and $t$ represents time periods. Parameter estimates can be obtained for each year separately, or data from a period of several years can be used to obtain long-run estimates of the parameters. The choice of a base city and occupation is arbitrary and will not affect the estimates of relative wage levels. The pattern of variation of the city effect over time for any one city will, however, depend on which city is chosen as the base.

${ }^{21}$ Real wages are computed by deflating nominal wages by a linear interpolation of the relative retail price indices from Table 1 . In the cities where no trend was apparent between 1869 and 1890-1898 (Pittsburgh, Chicago, Richmond, St. Louis, and San Francisco), I used the average of all three price level estimates. Where there was an apparent trend between 1869 and 1890-1898 (the other seven cities), I used the average of the estimates for 1890 and 1898 for these nine years and used a simple linear interpolation between this level and that for 1869 to compute the level in each of the intervening years. Initial estimates of intercity and interregional differentials indicated that coefficients varied only slightly from year to year and that comparisons could be simplified by estimating city and regional effects on data from five-year intervals. The use of a longer time period has the added advantage of smoothing out any short-run shocks to wages which might distort intercity comparisons in a single year. 
Economic agents are concerned with real wages, not nominal ones. For employers the relevant price is the one they receive for their products. To employers operating in national markets and receiving a uniform price for their products, the equalization of nominal wages was equivalent to the equalization of real wages and would have made employers largely indifferent to the location of their production activities. The question of labor market integration, however, is primarily concerned with the responsiveness of labor supply. From this perspective the relevant price is the expenditure necessary for a representative worker to obtain a given level of utility, so it is necessary to evaluate the effect of differences in the cost of living on money wages.

Adjusting for differences in the cost of living substantially alters the pattern of geographic wage differentials, introducing a much greater degree of variation. As Table 3 shows, variations between regions are more pronounced in real than in nominal terms, and variations within regions remain quite large. Within the Midwest real wages in the two northern cities-Chicago and St. Paul-exceeded those in their southern neighbors-Cincinnati and St. Louis-by as much as 10 to 20 percent. The range of variation among the eastern cities is comparable, although wage differences outside of New York appear to have been somewhat smaller. ${ }^{22}$ Despite intraregional differences, however, a clear pattern of variation is also apparent between regions. In Chicago, Cincinnati, St. Louis, and St. Paul the lower level of retail prices raised real wages, opening a substantial gap between these cities and those in the East. In Cincinnati rising prices and falling wages reduced this advantage appreciably, but there was no more generalized decline in midwestern real wages. The regional differential between midwestern and eastern wages fluctuated between 20 and 30 percent, with no indication of any significant convergence.

Even after adjusting for differences in the cost of living, Richmond remains the city with the lowest wages, although the gap between it and the eastern cities is reduced somewhat by the lower than average level of prices. In New Orleans the high but falling level of prices largely offset the decline in nominal wages, resulting in a persistent east-west wage gap within the South. Adjusting for differences in relative prices does not alter the convergence of wages in San Francisco toward eastern levels, leaving it almost as pronounced in real terms as it was in money terms.

Some sense of the significance of these magnitudes is provided by comparing them with interregional wage differentials at other dates. ${ }^{23}$

\footnotetext{
${ }^{22}$ There is some evidence discussed below to suggest that housing costs in New York were disproportionately large and that some of the variation in eastern wage levels may be attributable to the fact that this expense is not fully represented in the price index used in this section.

${ }^{23}$ An alternative comparison is provided by contemporaneous variations in the prices for other commodities. For example, wholesale prices for agricultural commodities, such as pork and wheat,
} 
TABLE 2

RELATIVE NOMINAL WAGE LEVELS, 1870-1898

\begin{tabular}{|c|c|c|c|c|c|c|}
\hline & $1870-1874$ & $1875-1879$ & $1880-1884$ & $1885-1889$ & $1890-1894$ & $1895-1898$ \\
\hline \multicolumn{7}{|l|}{ CITIES } \\
\hline \multicolumn{7}{|l|}{ Northeast } \\
\hline New York & 100.0 & 100.0 & 100.0 & 100.0 & 100.0 & 100.0 \\
\hline Boston & 103.1 & 96.9 & 91.6 & 91.7 & 91.2 & 92.1 \\
\hline Baltimore & 87.4 & 91.0 & 84.5 & 83.5 & 82.2 & 82.6 \\
\hline Philadelphia & 92.3 & 90.2 & 83.3 & 85.5 & 85.6 & 85.9 \\
\hline Pittsburgh & 89.6 & 83.0 & 84.4 & 85.7 & 88.3 & 87.2 \\
\hline \multicolumn{7}{|l|}{ Midwest } \\
\hline Cincinnati & 98.9 & 98.0 & 90.1 & 87.8 & 87.7 & 82.9 \\
\hline Chicago & 102.7 & 97.2 & 94.6 & 95.0 & 96.3 & 99.4 \\
\hline St. Louis & 85.3 & 93.7 & 90.0 & 87.7 & 89.2 & 89.4 \\
\hline St. Paul & 86.1 & 95.1 & 93.4 & 91.9 & 90.4 & 90.4 \\
\hline \multicolumn{7}{|l|}{ West } \\
\hline San Francisco & 141.3 & 139.2 & 119.2 & 118.0 & 111.8 & 112.2 \\
\hline \multicolumn{7}{|l|}{ South } \\
\hline Richmond & 77.1 & 77.8 & 70.6 & 69.2 & 69.1 & 68.2 \\
\hline New Orleans & 106.3 & 105.5 & 92.7 & 89.7 & 88.0 & 88.1 \\
\hline \multicolumn{7}{|l|}{ REGIONS } \\
\hline Northeast & 100.0 & 100.0 & 100.0 & 100.0 & . 100.0 & $\therefore 100.0$ \\
\hline Midwest & 98.5 & 104.2 & 104.2 & 101.8 & 102.0 & • . .101 .5 \\
\hline West & 149.9 & 151.3 & 135.2 & 133.0 & 125.9 & 126.2 \\
\hline South & 98.8 & 101.0 & 93.8 & 90.7 & 89.5 & 89.0 \\
\hline
\end{tabular}

Notes: City and regional effects are derived by exponentiating the city and regional effect estimated from a regression of the natural logarithm of wages in city $j$ and occupation $i\left(W_{i j}\right)$ on a series of dummy variables for each occupation and for each city or region. This regression expresses the log of wages as $\ln W_{i j}=\alpha+\rho_{i}+\pi_{j}+\varepsilon_{i j}$, where the intercept, $\alpha$, is the log of wages of street laborers in the excluded city or region, and the occupation effect, $\rho_{i}$, and the city or region effect, $\pi_{j}$, measure the incremental effect on the log of wages from being in occupation $i$ and city or region $j$. Source: U.S. Department of Labor, "Wages in the United States and Europe, 1870-1898," Bulletin of the Department of Labor, no. 18 (Sept. 1898), pp. 665-93.

Although precisely comparable wage data are not available for later dates, other studies indicate that the differential between midwestern and eastern real wages persisted at least until 1909, but that a substantial convergence must have taken place some time before the late 1930s. In 1909 a survey of wages and prices in American cities conducted by the British Board of Trade found a pattern of wages and retail prices quite similar to that described above. ${ }^{24}$ According to this report, a slight midwestern advantage in money wages was reinforced by the lower level of retail prices, resulting in real wage differentials of 5 to 15 percent for a group of occupations closely resembling those examined in this article. By the time of a National Industrial Conference Board survey

reveal interregional differentials that were typically less than 10 percent. U.S. Dept. of Agriculture, Report of the Commissioner, pp. 654-61; and U.S. Dept. of Agriculture, Report of the Secretary, pp. 322-33.

${ }^{24}$ Great Britain Board of Trade of London, Cost of Living in American Towns, reprinted by U.S. Senate, 62nd Congress, 2nd session, S. Doc. 22, vol. 4 (Washington, DC, 1911). 
TABLE 3

RELATIVE REAL WAGE LEVELS, 1870-1898

\begin{tabular}{lrrrrrr}
\hline \hline & $1870-1874$ & $1875-1879$ & $1880-1884$ & $1885-1889$ & $1890-1894$ & $1895-1898$ \\
\hline CITIES & & & & & & \\
Northeast & & & & & & \\
$\quad$ New York & 100.0 & 100.0 & 100.0 & 100.0 & 100.0 & 100.0 \\
Boston & 92.2 & 89.8 & 88.0 & 91.3 & 92.8 & 93.7 \\
$\quad$ Baltimore & 84.6 & 91.6 & 88.5 & 91.1 & 91.9 & 92.3 \\
$\quad$ Philadelphia & 94.7 & 92.0 & 84.4 & 86.1 & 85.9 & 86.2 \\
$\quad$ Pittsburgh & 94.3 & 88.9 & 92.1 & 95.1 & 99.0 & 97.7 \\
Midwest & & & & & & \\
$\quad$ Cincinnati & 120.8 & 117.7 & 106.5 & 102.1 & 101.1 & 95.6 \\
Chicago & 123.1 & 118.7 & 117.5 & 120.0 & 123.0 & 126.9 \\
$\quad$ St. Louis & 100.9 & 112.8 & 110.4 & 109.3 & 112.4 & 112.6 \\
$\quad$ St. Paul & 110.2 & 122.4 & 120.8 & 119.4 & 117.5 & 119.1 \\
West & & & & & & \\
$\quad$ San Francisco & 135.6 & 136.0 & 118.5 & 119.4 & 114.3 & 114.7 \\
South & & & & & & \\
$\quad$ Richmond & 85.6 & 87.9 & 81.2 & 81.0 & 81.7 & 80.6 \\
$\quad$ New Orleans & 97.2 & 102.4 & 95.5 & 98.2 & 100.1 & 100.3 \\
REGIONS & & & & & & \\
$\quad$ Northeast & 100.0 & 100.0 & 100.0 & 100.0 & 100.0 & 100.0 \\
$\quad$ Midwest & 122.5 & 128.0 & 126.3 & 121.8 & 121.2 & 120.5 \\
$\quad$ West & 146.2 & 147.5 & 131.8 & 129.6 & 122.6 & 122.9 \\
$\quad$ South & 97.2 & 102.0 & 97.2 & 96.5 & 96.9 & 96.3 \\
\hline
\end{tabular}

Notes: The method of computing the city effects in this table is identical to that described in the Table 2 notes with the exception that the wage data have been deflated by the cost-of-living estimates from Table 1.

Source: See Table 2.

based on payroll records from 1937, however, real wages in the Midwest were only about 3 to 5 percent above those in the East. ${ }^{25}$ More recent work, employing data from the 1967 Census of Manufactures, found that the differential was between 4.6 and 8.4 percent, depending on the price index used to adjust for geographic differences in the cost of living. ${ }^{26}$

The relative real wage levels reported in Table 3 reflect only that portion of the intercity wage variation caused by factors common to all 23 occupations covered by the data. The actual relative wage levels will be distributed around this value, reflecting the effects of differences in the extent of product market integration, institutional differences in the operation of labor markets for various occupations, or differences in the magnitude of local market disturbances producing systematic variations in the level of relative wages. The extent of this variation around the overall city effect may be examined by adding interaction terms to the regression, allowing the city effects for certain occupations or groups of occupations to differ from the overall level.

\footnotetext{
${ }^{25}$ Margaret Ada Beney, Differentials in Industrial Wages and Hours in the United States, National Industrial Conference Board Studies, no. 238 (New York, 1938).

${ }^{26}$ Philip R. P. Coelho and Moheb A. Ghali, "The End of the North-South Wage Differential: Reply," American Economic Review, 63 (Sept. 1973), pp. 757-62.
} 
Table 4 shows relative real wage rates calculated separately for the three most numerous groups of occupations in the sample-skilled construction workers and skilled and semiskilled metal workers-as well as for common laborers. Although relative real wage rates for each occupation group varied around the overall city levels (as shown in Table 3), their departures were not particularly striking. Within the eastern cities only relative wages for skilled construction workers in Boston were significantly different from those for all occupations in the city for an extended period of time. In the midwestern cities wages deviated more noticeably. With the exception of Cincinnati and the semiskilled metal workers in St. Louis, the relative level of wages in the metal-working trades was well above the overall city level, resulting in an even greater real wage differential between these cities and those in the East. ${ }^{27}$

Among the southern and western cities, only New Orleans reveals any marked variation across occupation groups. In San Francisco the relative wages of the different occupation groups were clustered closely around the overall level, departing significantly in only a few years. Similarly, in Richmond there was little variation in relative wages across the different occupation groups. In New Orleans, on the other hand, the wages of skilled construction workers were significantly below the overall city effect, while those for the two metal-working trades were appreciably above the overall city effect. While it is possible that the relatively high level of metal-working wages in New Orleans is a reflection of integration with the midwestern cities, the large divergence between relative wage levels in the construction and metal-working trades might also be interpreted as an indication of the general isolation of this city from the prevailing norms determining the relative wages of workers in different occupations.

\section{INTERPRETING INTERCITY VARIATION IN REAL WAGE LEVELS}

The existence of large and persistent intercity real wage differentials, especially those between the East and Midwest, in the decades after the Civil War is in striking contrast to the general perception of the late nineteenth century as a period of increasing geographic integration. ${ }^{28}$

\footnotetext{
${ }^{27}$ The low relative wage level of the semiskilled metal workers in St. Louis appears, however, to be caused by one extremely low wage occupation, machinists' helpers. Dropping this series from the estimates results in only a minor adjustment of the overall level of wages but raises the relative wages of semiskilled metal workers substantially. Excluding machinists' helpers, relative wages of semiskilled metal workers in St. Louis were 101.5 in the $1870-1874$ period, around 110 between the 1875-1879 and 1885-1889 periods, and reached 133.3 in the 1895-1898 period.

${ }^{28}$ Although the differentiation of northern and southern labor markets has long been a theme in U.S. economic history, the distinction between antebellum midwestern and northeastern labor markets has only recently been noted. See Alexander James Field, "Sectoral Shift in Antebellum Massachusetts: A Reconsideration," Explorations in Economic History, 15 (Apr. 1978), pp.
} 
TABLE 4

RELATIVE REAL WAGE LEVELS FOR SPECIFIED GROUPS OF OCCUPATIONS, 1870-1898

\begin{tabular}{|c|c|c|c|c|c|c|}
\hline & $1870-1874$ & $1875-1879$ & $1880-1884$ & $1885-1889$ & $1890-1894$ & $1895-1898$ \\
\hline \multicolumn{7}{|c|}{ SKILLED CONSTRUCTION WORKERS } \\
\hline \multicolumn{7}{|c|}{ Northeast } \\
\hline New York & 100.0 & 100.0 & 100.0 & 100.0 & 100.0 & 100.0 \\
\hline Boston & 85.5 & $80.0^{\mathrm{a}}$ & $76.8^{\mathrm{a}}$ & $81.5^{\mathrm{a}}$ & $83.2^{\mathrm{a}}$ & $81.1^{\mathrm{a}}$ \\
\hline Baltimore & 88.2 & 97.7 & 91.3 & 91.1 & 90.9 & $82.2^{\mathrm{a}}$ \\
\hline Philadelphia & 95.9 & 94.0 & 76.5 & $79.5^{\mathrm{a}}$ & 81.5 & $77.9^{\mathrm{a}}$ \\
\hline Pittsburgh & 89.5 & 85.8 & 88.4 & 94.5 & 97.1 & $89.2^{\mathrm{a}}$ \\
\hline \multicolumn{7}{|l|}{ Midwest } \\
\hline Cincinnati & 114.3 & 113.0 & $98.0^{\mathrm{a}}$ & 98.0 & 96.7 & $83.5^{\mathrm{a}}$ \\
\hline Chicago & $107.6^{\mathrm{a}}$ & $107.3^{\mathrm{a}}$ & $109.5^{\mathrm{b}}$ & $113.2^{\mathrm{b}}$ & $114.1^{\mathrm{b}}$ & $114.3^{\mathrm{a}}$ \\
\hline St. Louis & 102.4 & $127.7^{\mathrm{a}}$ & $120.3^{\mathrm{a}}$ & 112.9 & 116.1 & 107.9 \\
\hline St. Paul & 103.1 & 119.8 & 122.1 & 118.8 & $105.1^{\mathrm{a}}$ & $100.0^{\mathrm{a}}$ \\
\hline \multicolumn{7}{|l|}{ West } \\
\hline San Francisco & 135.5 & 137.6 & 113.0 & $110.1^{\mathrm{a}}$ & $105.8^{b}$ & $101.2^{\mathrm{a}}$ \\
\hline \multicolumn{7}{|l|}{ South } \\
\hline Richmond & $95.4^{\mathrm{b}}$ & $96.2^{\mathrm{a}}$ & 83.8 & 81.3 & 80.4 & 74.2 \\
\hline New Orleans & $74.3^{\mathrm{a}}$ & $83.6^{\mathrm{a}}$ & $76.9^{\mathrm{a}}$ & $77.5^{\mathrm{a}}$ & $86.7^{\mathrm{a}}$ & $80.7^{\mathrm{a}}$ \\
\hline \multirow{2}{*}{\multicolumn{7}{|c|}{$\begin{array}{l}\text { SKILLED METAL WORKERS } \\
\text { Northeast }\end{array}$}} \\
\hline \multicolumn{6}{|c|}{ Northeast } & \\
\hline New York & 100.0 & 100.0 & 100.0 & 100.0 & 100.0 & 100.0 \\
\hline Boston & $112.4^{\mathrm{a}}$ & 93.9 & 93.4 & 92.7 & 94.0 & 100.1 \\
\hline Baltimore & 87.5 & 88.2 & 89.9 & 90.6 & 89.3 & 96.4 \\
\hline Philadelphia & 97.0 & 84.0 & 85.6 & 85.1 & 81.4 & 86.1 \\
\hline Pittsburgh & 94.0 & 85.4 & 92.4 & 92.9 & $92.1^{\mathrm{b}}$ & 97.4 \\
\hline \multicolumn{7}{|l|}{ Midwest } \\
\hline Cincinnati & 130.7 & 109.7 & 108.0 & 97.6 & $94.3^{\mathrm{b}}$ & 95.7 \\
\hline Chicago & $146.1^{\mathrm{a}}$ & 126.2 & $127.3^{b}$ & 126.6 & 127.8 & $136.8^{\mathrm{b}}$ \\
\hline St. Louis & $124.1^{\mathrm{a}}$ & 119.3 & 116.9 & 114.3 & 114.0 & 120.1 \\
\hline St. Paul & $149.7^{\mathrm{a}}$ & $141.2^{\mathrm{a}}$ & $134.7^{\mathrm{a}}$ & $130.6^{\mathrm{a}}$ & $134.0^{\mathrm{a}}$ & $139.1^{\mathrm{a}}$ \\
\hline \multicolumn{7}{|l|}{ West } \\
\hline San Francisco & 141.7 & 128.6 & 120.1 & 121.8 & 115.2 & 122.5 \\
\hline \multicolumn{7}{|l|}{ South } \\
\hline Richmond & $100.4^{\mathrm{a}}$ & 94.7 & 89.1 & 83.9 & 80.3 & 82.3 \\
\hline New Orleans & $127.1^{\mathrm{a}}$ & $111.6^{\mathrm{b}}$ & $110.4^{\mathrm{a}}$ & $110.5^{\mathrm{a}}$ & $110.4^{\mathrm{a}}$ & $119.8^{\mathrm{a}}$ \\
\hline \multirow{2}{*}{\multicolumn{7}{|c|}{$\begin{array}{l}\text { SEMISKILLED METAL WORKERS } \\
\text { Northeast }\end{array}$}} \\
\hline & & & & & & \\
\hline New York & 100.0 & 100.0 & 100.0 & 100.0 & 100.0 & 100.0 \\
\hline Boston & 84.8 & 92.3 & 89.2 & 98.0 & $102.7^{\mathrm{a}}$ & $116.6^{\mathrm{a}}$ \\
\hline Baltimore & $73.6^{\mathrm{a}}$ & 85.1 & 85.6 & 91.7 & 94.3 & $107.8^{\mathrm{a}}$ \\
\hline Philadelphia & 90.1 & 87.6 & 84.6 & 87.3 & 90.2 & $96.9^{\mathrm{a}}$ \\
\hline Pittsburgh & 86.6 & 85.9 & 88.2 & 92.1 & 97.6 & 105.8 \\
\hline \multicolumn{7}{|l|}{ Midwest } \\
\hline Cincinnati & $109.2^{\mathrm{b}}$ & 120.9 & 108.5 & 101.4 & 101.3 & $107.7^{\mathrm{a}}$ \\
\hline Chicago & 129.0 & 129.6 & 122.7 & $129.7^{b}$ & $136.5^{\mathrm{a}}$ & $153.3^{\mathrm{a}}$ \\
\hline St. Louis & $80.0^{\mathrm{a}}$ & $90.2^{\mathrm{a}}$ & $86.5^{\mathrm{a}}$ & $90.9^{\mathrm{a}}$ & $94.7^{\mathrm{a}}$ & 108.9 \\
\hline St. Paul & $125.8^{b}$ & $135.3^{b}$ & $132.6^{\mathrm{b}}$ & $134.6^{\mathrm{b}}$ & $142.3^{a}$ & $154.7^{\mathrm{a}}$ \\
\hline \multicolumn{7}{|l|}{ West } \\
\hline San Francisco & 131.1 & 134.6 & 123.0 & $131.4^{b}$ & $127.2^{\mathrm{a}}$ & $143.7^{\mathrm{a}}$ \\
\hline \multicolumn{7}{|l|}{ South } \\
\hline Richmond & $66.3^{\mathrm{a}}$ & $69.2^{\mathrm{a}}$ & $66.2^{\mathrm{a}}$ & $67.2^{\mathrm{a}}$ & $68.1^{\mathrm{a}}$ & 76.7 \\
\hline New Orleans & 102.1 & $113.0^{\mathrm{b}}$ & 102.6 & $109.4^{\mathrm{a}}$ & $109.4^{b}$ & $122.7^{\mathrm{a}}$ \\
\hline
\end{tabular}


TABLE 4-Continued

\begin{tabular}{lcccccr}
\hline & $1870-1874$ & $1875-1879$ & $1880-1884$ & $1885-1889$ & $1890-1894$ & $1895-1898$ \\
\hline COMMON LABORERS & & & & & & \\
Northeast & & & & & & \\
$\quad$ New York & 100.0 & 100.0 & 100.0 & 100.0 & 100.0 & 100.0 \\
Boston & $66.5^{\mathrm{a}}$ & 87.5 & 88.8 & 89.5 & 87.6 & 91.7 \\
$\quad$ Baltimore & $66.3^{\mathrm{b}}$ & 80.7 & 81.4 & 82.5 & 83.2 & 89.5 \\
$\quad$ Philadelphia & $77.1^{\mathrm{b}}$ & 89.7 & 87.9 & 91.5 & 89.7 & 96.4 \\
$\quad$ Pittsburgh & & & & & & \\
Midwest & & & & & & \\
$\quad$ Cincinnati & 114.4 & 118.6 & 114.3 & 108.6 & 112.1 & 115.4 \\
Chicago & 111.2 & 122.4 & 120.0 & 114.9 & 114.6 & 122.7 \\
$\quad$ St. Louis & 88.1 & 115.9 & 114.3 & 113.3 & 112.6 & 121.1 \\
$\quad$ St. Paul & $79.4^{\mathrm{a}}$ & 106.5 & 120.6 & 120.3 & 120.9 & 125.2 \\
West & & & & & & \\
$\quad$ San Francisco & $107.5^{\mathrm{b}}$ & 133.3 & 123.6 & 122.1 & 106.4 & 108.8 \\
South & & & & & & \\
$\quad$ Richmond & & & & & & \\
$\quad$ New Orleans & $68.1^{\mathrm{a}}$ & 99.2 & 96.1 & 109.2 & 98.1 & 91.1 \\
\hline
\end{tabular}

${ }^{a}$ Occupation-specific city effect is statistically significantly different from the city effect for all occupations at the 1 percent level.

${ }^{b}$ Occupation-specific city effect is statistically significantly different from the city effect for all occupations at the 5 percent level.

Notes: The relative real wages reported here are obtained by regressing the logarithm of real wages in city $j$ and occupation $i\left(W_{i j}\right)$ on a series of dummy variables for each city and occupation and a set of interactions between dummy variables for each group of occupations and the city dummies. The log of wages may then be expressed as $\ln W_{i j}=\alpha+\rho_{i}+\pi_{j}+\psi_{n j}+\varepsilon_{i j}$, where the city effect, $\pi_{j}$, measures the incremental effect on wages for all occupations of being in city $j$, and the coefficient on the interaction term, $\psi_{n j}$, measures the difference between the city effect for all occupations and the city effect for the $n$th subset of occupations in city $j$.

Source: See Table 2.

These differentials suggest that significant variations in the relative scarcity of labor persisted over more than three decades and that potential opportunities for arbitrage went unexploited. This condition prevailed primarily because of the high costs of acquiring information. Direct costs of transportation would have been only a slight deterrent early in the period and would have posed no problem by the turn of the century. By the early 1870 s a well-developed railroad network provided passenger connections throughout the East and Midwest, and a special system of "emigrant" trains offered reduced fares to the interior. ${ }^{29} \mathrm{By}$ 1870 it was possible to travel from New York to Chicago for just $\$ 13.00 .^{30}$

146-71; and Paul A. David, "Industrial Labor Market Adjustment in a Region of Recent Settlement: Chicago, 1848-1868," in Peter Kilby, ed., Quantity and Quiddity: Essays in U.S. Economic History (Middletown, CT, 1987).

${ }^{29}$ Although this service was neither as comfortable nor as fast as first-class passenger service, fares were two-thirds the regular rate, and travel times to the major cities of the interior were only two or three days.

${ }^{30}$ Fares to St. Louis, $\$ 16.10$, and St. Paul, $\$ 33.00$, were somewhat higher than those to Chicago, but they fell more quickly in the succeeding years. Frank B. Goddard, Where to Emigrate and Why 
While this sum represented about nine days' wages to a common laborer, it was small compared to the potential increase in real wages. As documented in the previous section, real daily wages in Chicago exceeded those in eastern cities by 20 percent, so it would have taken just 43 days to recoup the investment in such a ticket. The only city for which the cost of transportation was likely to have been a significant barrier was San Francisco. In 1870 the fare on the newly opened transcontinental railroad was $\$ 160.00$, but fare reductions over the next 30 years were most pronounced on long-distance routes, and by the turn of the century the difference between fares to San Francisco and cities in the Midwest had been greatly reduced. ${ }^{31}$

The differentials do not arise from problems in measuring real wages for homogeneous labor services. The prediction that increased labor market integration would be reflected in increased equalization of real wage levels applies strictly only to "real wages for homogeneous labor services." Discrepancies between this theoretical construct and measured wages may arise either because of biases in the measurement of the cost of living or because the wage data do not refer to strictly homogeneous labor services, and either of these factors could produce the appearance of intercity wage differentials even in a completely integrated market. Although it is difficult to assess the importance of these sources of measurement error, the available data offer no evidence that they played an important role in explaining the persistence of intercity real wage variations.

In fact, it appears that any bias in the measured relative costs of living works to understate the real wage gap and narrow it over time. The chief deficiency in the cost-of-living index is that it relies entirely on food items, excluding other items of consumption. After food, housing was the single largest item of expenditure and the one that varied the most between regions. ${ }^{32}$ Yet both the magnitude and nature of the variations in housing costs that would have been necessary to offset the pattern of real wage variation described above appear implausible. Taking the level of nominal wages and retail food prices as given, the level of housing costs in Chicago would have had to exceed those in New York by over 50 percent to equate real wages in the two cities. ${ }^{33}$ Since real wages in the other eastern cities were lower than in New York, an even

(Philadelphia, 1869), pp. 583-84; and W. Hoff and F. Schwabach, North American Railroads: Their Administration and Economic Policy (New York, 1906), p. 244.

${ }^{31}$ Hoff and Schwabach, North American Railroads, p. 244.

${ }^{32}$ Coelho and Shepherd, "Differences in Regional Prices," pp. 573-76.

${ }^{33}$ This calculation assumes that the prices of other commodities varied with a weighted average of food and housing costs and assigns weights of 0.7 and 0.3 to food and housing, respectively. The differential in housing costs implied for St. Louis ( 8 percent) and St. Paul (23 percent) are smaller but appear unlikely in light of the limited evidence on spatial variations in housing costs that is reviewed below. 
larger differential in housing costs would be required to bring midwestern wages into equality with those in the other eastern cities.

The possibility of large variations in housing quality within and between cities makes comparisons of actual housing costs in different locations tentative, but it appears they would have accentuated, not offset, differences in food costs. Coelho and Shepherd's regional price level estimates for 1870 to 1880 show that although rents in the East North Central region were approximately one-third higher than those in New England, they were from 8 to 14 percent below those in the Middle Atlantic region during most of the decade. ${ }^{34}$ Table 5 presents data from two other studies of housing costs. Although the data for 1869 indicate that housing costs were higher in the Midwest than in the East, the data for 1909 are consistent with Coelho and Shepherd's estimates. The divergence between the 1869 state-level estimates and Coelho and Shepherd's regional estimates for the 1870 s provides some indication of the potential variability of housing cost estimates. While little is known about the method used in collecting the data on which these earlier estimates rest, the British Board of Trade, which collected the data for 1909 , went to great lengths in its efforts to control for quality variations. To that extent, its estimates showing lower housing costs in the Midwest would appear to be more reliable than either of the estimates based on earlier data. Thus, although inclusion of housing costs might have reduced real wage differentials at the beginning of the period, the subsequent decline in midwestern housing costs indicated by the data from 1909 would have contributed to interregional divergence of real wages.

Turning to the measurement of nominal wage levels, a variety of sources of heterogeneity are possible, but none were of any substance in the period in question. There are two broad categories of heterogeneity, the first arising because of variations in the character of the work or other nonwage aspects of the labor bargain and the second resulting from differences in the quality of workers performing otherwise identical jobs. Although the wage data are for narrowly defined occupations and were intended to be comparable, some degree of variation in job characteristics is still possible. This variation would not, however, affect overall geographic wage differentials unless job characteristics in the different occupations varied systematically across cities. There is no way to assess this possibility, but it would be difficult to reconcile the

\footnotetext{
${ }^{34}$ The precise magnitude of the interregional differentials fluctuated considerably over the course of the decade. While the differential between New England and the East North Central region remained fairly steady during these years, the rents in the Middle Atlantic region converged somewhat toward those in the East North Central region. Coelho and Shepherd, "Differences in Regional Prices," p. 591.
} 
TABLE 5

RELATIVE RENTAL HOUSING COSTS, 1869-1909

\begin{tabular}{|c|c|c|c|}
\hline & \multirow{2}{*}{$\begin{array}{l}\text { Average Across } \\
\text { All Cities = } 100 \\
1869\end{array}$} & \multicolumn{2}{|c|}{ New York $=100$} \\
\hline & & 1869 & 1909 \\
\hline \multicolumn{4}{|l|}{ Northeast } \\
\hline Boston & 98.9 & 116.1 & 82.0 \\
\hline New York & 85.2 & 100.0 & 100.0 \\
\hline Philadelphia & 57.0 & 67.7 & 79.0 \\
\hline Baltimore & 68.1 & 80.4 & 54.0 \\
\hline Pittsburgh & 57.0 & 67.7 & 94.1 \\
\hline \multicolumn{4}{|l|}{ Midwest } \\
\hline Cincinnati & 78.9 & 92.7 & 93.1 \\
\hline Chicago & 111.8 & 131.4 & 70.1 \\
\hline St. Louis & 122.2 & 143.5 & 101.1 \\
\hline St. Paul & 107.1 & 125.7 & 77.0 \\
\hline \multicolumn{4}{|l|}{ West } \\
\hline San Francisco & 138.9 & 163.9 & \\
\hline \multicolumn{4}{|l|}{ South } \\
\hline Richmond & 95.8 & 112.1 & \\
\hline New Orleans & 179.7 & 211.3 & 72.0 \\
\hline
\end{tabular}

Notes and Sources: For 1869 housing costs are computed as an unweighted average of the rent for four- and six-room apartments as reported for the cities in each state in U.S. Treasury Department, Bureau of Statistics, The Costs of Labor and Subsistence in the United States for the Year 1869, by Edward Young (Washington, DC, 1870). The index for 1909 is taken from Great Britain Board of Trade of London, Cost of Living in American Towns, reprinted by U.S. Senate, 62nd Congress, 2nd session, S. Doc. 22, vol. 4 (Washington, DC, 1911), pp. xxxvii-xxxviii.

emergence of such systematic differences with the notion of an integrated market. ${ }^{35}$

Employment relationships involve a broad array of variables, and it is possible that intercity differences in nonwage aspects of the labor bargain were reflected in compensating variations in wages among workers performing otherwise identical tasks. Fringe benefits were unimportant for manual workers in the nineteenth century and so could not explain much wage variation, and the scattered facts available do not suggest that differences in the length of the work day, the extent of seasonality, or the risk of unemployment explain the intercity variation in real wages.

The Labor Department said nothing about these issues in reporting the wage data used here, and there are only fragments of information on spatial variation in these features of the employment relationship. The 1890 Census of Manufactures, for example, reports both average daily hours and the typical number of weeks in operation for selected industries in major cities. In foundries and machine shops, which

35 If employers in various cities were in fact engaged in production requiring employees with different qualifications, then there would be in effect no basis for labor market arbitrage between different cities, and the question of labor market integration would be moot. 
employed many of the metal workers included in the wage data, average daily hours in the high-wage midwestern cities exceeded those in most eastern cities by no more than 2 to 3 percent. ${ }^{36}$ Seasonality in employment appears to have been equally invariant across locations: the typical number of weeks in operation ranged from 49.8 in St. Paul to 51.6 in New York. Seasonal work patterns were probably more important in the construction trades, but the binding constraint in extending the work year in construction arose not from inclement weather but from the organization of the industry. Summarizing the results of a number of studies from the early twentieth century, William Haber concluded that despite extreme variations in climate, the number of days worked in cities such as New York, St. Paul, and Montreal was "about the same" as in Los Angeles, San Francisco, and New Orleans. ${ }^{37}$ Finally, although there were differences in the risks of unemployment, the census data for 1890 and 1900 reveal no systematic relationship with wages. $^{38}$

The second possible source of intra-occupation variations in wage rates is variation in the quality of workers between cities. Since the wage data are averages over a number of employees, random variations in individual ability should not be a major source of geographic differentials, and there do not appear to be any systematic variations in population characteristics across cities. Although no data bearing directly on differences in productivity are available, it is possible to measure geographic variations in a number of observable characteristics-sex, race, age, and ethnicity-which are often treated as proxies

\footnotetext{
${ }^{36}$ For the summer months the greatest difference was about 6.5 percent between Chicago ( 9.94 hours) and Baltimore (9.33 hours). In the winter months hours in a number of the eastern cities actually exceeded those in midwestern cities. U.S. Department of the Interior, "Manufactures: Statistics of Cities," Eleventh Census of the United States (1890), vol. 12 (Washington, DC, 1895), pp. 724-33. The impression that the length of the work day did not vary systematically across locations is confirmed by data presented in U.S. Department of Interior, "Report on the Statistics of Wages in Manufacturing Industries with Supplementary Reports," Tenth Census of the United States (1880), vol. 20 (Washington, DC, 1886), pp. xxviii-xxxiii.

${ }^{37}$ William Haber, Industrial Relations in the Building Industry, Wertheim Fellowship Publications, no. 3 (Cambridge, MA, 1930), pp. 97-115.

${ }^{38}$ U.S. Department of the Interior, Eleventh Census (1890), "Population," part 2 (Washington, DC, 1897), pp. 630-743; and U.S. Department of Commerce and Labor, Bureau of the Census, Occupations at the Twelfth Census (Washington, DC, 1904), pp. 480-743. The computation of unemployment rates is discussed in Rosenbloom, "Labor Market Institutions," pp. 116-17. Unemployment rates in the Midwest exceeded those in the East in 1900, but unemployment rates in the two regions were similar in 1890 . It might be hypothesized that workers are primarily concerned about the risk of unemployment during cyclical downturns, making the 1900 figures the more relevant ones and suggesting that a portion of the higher real wage in the midwestern cities compensated workers for a narrower and hence more unstable employment base. It is difficult to believe, however, that the differences in unemployment rates were large enough to account for more than a small part of the 20 to 25 percent difference in real wages between eastern and midwestern cities in the 1890 s. In addition, the growth of the midwestern cities seems likely to have increased rather than reduced the diversity of employment opportunities over time, thus reducing the risk of unemployment in these cities.
} 
for labor quality. Because very few women were employed in the manual trades covered by the wage data, and blacks accounted for only a small proportion of the labor force in eastern and midwestern cities, we may concentrate on the effects of intercity variations in the age distribution and ethnic make-up of the labor force. Census data reveal that the proportion of the labor force in the 25 to 44 age group was highest in the midwestern cities and San Francisco, but that the extent of this difference was diminishing over time. ${ }^{39}$ Since the 25 to 44 age group is likely to have the highest labor force participation rate and is less likely to have established strong geographic attachments than older workers, this is precisely the pattern of heterogeneity that we would expect to find in response to a geographic differential in real wages. Nonetheless, the pattern is not sharp enough to account for the wage differential. Although workers in the 25 to 44 age group were likely to be more productive than other workers, the small magnitude of the geographic variation in age distributions and their convergence over time indicate that this factor could not have contributed appreciably to explaining the real wage differential between the midwestern and eastern cities. Intercity differences in ethnic composition also look more like the consequence than the cause of real wage variation. In contrast to the expectation that the presence of less skilled immigrant workers would exert a downward pressure on wages, both the percentage of the population foreign born and the percentage of the foreign born from southern and eastern Europe are positively correlated with real wage levels. ${ }^{40}$

If, as the preceding evidence suggests, intercity real wage variations reflected genuine differences in the economic opportunities offered in various locations, we should find positive signs of this in aggregate migration rates. In particular, the conclusion that cities with the highest levels of real wages were in fact attracting the greatest volume of migration would confirm the impression that labor market conditions in those cities were more favorable than in cities with lower wage rates, but that the difficulty of acquiring and acting on information about these opportunities prevented more complete equalization of wages.

From 1870 to 1900 the population of the two midwestern cities with

\footnotetext{
${ }^{39}$ Rosenbloom, "Labor Market Institutions," pp. 118-19.

${ }^{40}$ Data on country of birth are available in each of the four decennial censuses from 1880 through 1900 for all 12 cities and in 1870 for all of the cities except St. Paul. U.S. Department of the Interior, Compendium of the Ninth Census (1870) (Washington, DC, 1872), table 20; U.S. Department of the Interior, Compendium of the Tenth Census (1880), part 1 (Washington, DC, 1883), table 33; U.S. Department of the Interior, Eleventh Census (1890), "Population," part 1 (Washington, DC, 1897), table 34; and U.S. Department of Commerce and Labor, Abstract of the Twelfth Census (1900) (Washington, DC, 1904), tables 81,82 . The correlation between the log of relative real wages and the fraction of the population foreign born in the four census years (using wages in 1898 for 1900) is 0.71 , while the correlation between the fraction of the foreign born from countries other than Germany, Great Britain, and Ireland is 0.45 .
} 


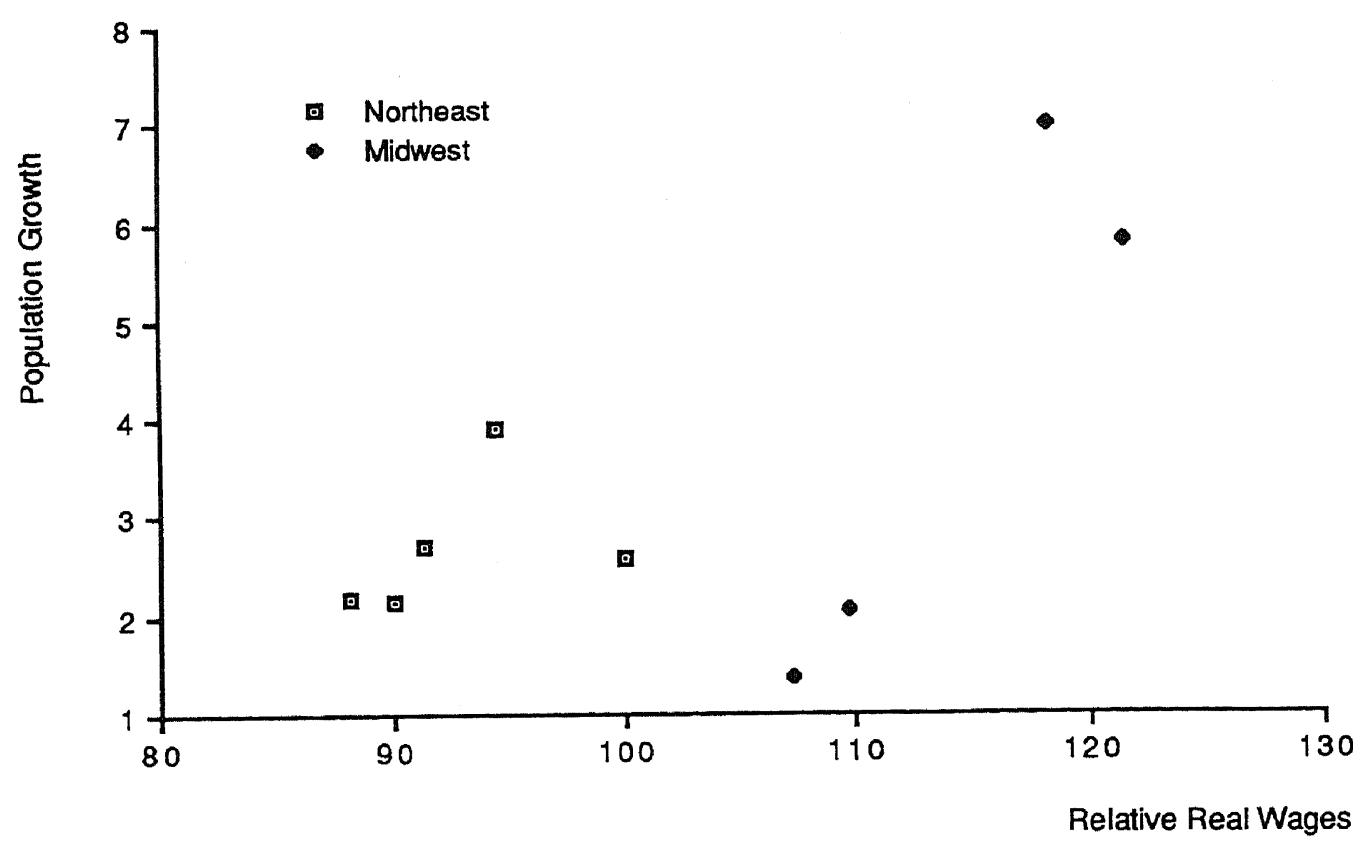

FIGURE 1

AVERAGE ANNUAL RATE OF POPULATION GROWTH AND AVERAGE RELATIVE REAL WAGE RATE, 1870-1900

the highest real wage levels-Chicago and St. Paul-grew by more than 5 percent per annum, a rate of growth which resulted in a more than fivefold increase in population over the period. Clearly such rapid growth could not have been achieved without a substantial influx of population. ${ }^{41}$ Rates of growth in the other seven northeastern and midwestern cities were distinctly slower, but, as Figure 1 suggests, they were roughly correlated with variations in relative real wage levels, although it appears that midwestern cities required higher wage levels to maintain any given rate of population growth. Given the huge increase in labor supply that these data reveal for Chicago and St. Paul, it is certainly remarkable that there was no appreciable reduction in relative real wages in these cities. Such a situation can only be explained by a correspondingly rapid outward movement of the labor demand schedule in these cities.

\section{CONCLUSIONS}

Although the behavior of wages provides only an imperfect indication of the extent of labor market integration, the evidence examined in this

${ }^{41}$ Although the rate of net immigration into individual cities cannot be measured directly, variations in rates of population growth are likely to be a good proxy for this variable. According to estimates by Paul A. David, "Industrialization and the Changing Labor Supply in a Region of Recent Settlement," Memorandum 25-26, Research Center in Economic Growth (Stanford, 1963), migration accounted for between three-fourths and four-fifths of the growth in Chicago's population in the decades between 1870 and 1900. 
article leaves little doubt that late nineteenth-century labor markets remained far from completely integrated. Where the barriers of distance were largest, improvements in transportation and communication did make a difference, as indicated by the convergence of real wages in San Francisco toward those in the rest of the country. Over shorter distances, however, there was no consistent reduction in geographic differentials. Most striking is the conclusion that real wages in midwestern cities were more than 20 percent higher than those in eastern cities. Although intraregional differentials were not as large, a considerable wage gap also persisted within the Northeast and Midwest. Measurements of real wage levels are subject to a variety of biases, of course, but neither these biases nor the direct costs of movement between locations seems capable of accounting for the observed pattern of real wage variation, at least within the eastern and midwestern cities. While it appears justified to interpret these differentials as an indication of the persistence of substantial intercity differences in labor scarcity, the rapid growth of population in the high wage cities of the Midwest suggests that these differentials reflect the interaction of large geographic variations in the rate of growth of labor demand with imperfections in the labor market. As a result, a complete account of labor market integration in the late nineteenth century will require disentangling the simultaneous effects of supply and demand factors in determining local wage rates.

\section{Appendix}

\section{CONSTRUCTION OF COST-OF-LIVING INDICES}

Ideally, comparison of the cost of living would be based on the minimum cost of obtaining an identical level of utility in each location. ${ }^{42}$ In practice, however, comparisons of relative consumer price levels in different regions are usually made using a fixed weight Laspeyres index of retail prices, in which the cost of a fixed bundle of goods is computed in terms of the prices prevailing in the different regions. Historical data on expenditures are in the form of expenditure shares, however, and this has led previous researchers to construct estimates of the relative level of prices as weighted averages of price relatives. ${ }^{43}$ Thus, the index for city $j$ is computed as

$$
P_{j}=\sum_{k} w_{k}\left(P_{j k} / P_{k}\right)
$$

\footnotetext{
42 John H. Pencavel, "Constant-Utility Index Numbers of Real Wages," American Economic Review, 67 (Mar. 1977), pp. 91-100.

${ }^{43}$ See, for example, Ethel D. Hoover, "Retail Prices After 1850," in Trends in the American Economy in the Nineteenth Century, National Bureau of Economic Research, Studies in Income and Wealth, vol. 24 (Princeton, 1960), pp. 140-90; and Coelho and Shepherd, "Differences in Regional Prices," pp. 551-91.
} 
where $w_{k}$ is the weight given to commodity $k, P_{j k}$ is the price of commodity $k$ in city $j$, and $P_{k}$ is the price of commodity $k$ in the base region. If these weights had been derived by computing the expenditure shares from the base region quantities and prices, so that

$$
w_{k}=Q_{k} P_{k} / \sum_{k} Q_{k} P_{k}
$$

then equation 2 would reduce to a Laspeyres price index. Since the expenditure weights were derived independently of the prices, however, this is not strictly true.

The estimates of relative retail food prices in this article were computed using equation 2, taking the average price of each commodity across all cities as the base. The commodities used in constructing the index and their weights are listed in Table 6. The list of commodities for which prices were available closely paralleled those used by Philip Coelho and James Shepherd in constructing their regional price level estimates for the years from 1851 to 1880 . Rather than deriving a new set of weights I have adapted their commodity weights by redistributing the weights for missing commodities to other similar ones. ${ }^{44}$ Although state and federal labor bureaus began conducting expenditure studies in the mid-1870s, it was not until the 1890s that these studies provided sufficient detail to allow the calculation of detailed commodity weights. ${ }^{45}$ The weights calculated by Coelho and Shepherd are based on data from the 2,561 "normal" families studied by the U.S. Bureau of Labor in 1890 to $1891 .^{46}$

For 1869 the price quotations are taken from a report by Edward Young which was published by the Treasury Department. This source provides only a single quotation for each commodity in each state. ${ }^{47}$ For 1890 and 1898, data were taken from surveys of retail food prices conducted by the Department of Labor. These surveys report a number of quotations for each commodity in each city. ${ }^{48}$ For these latter years the price in each city is taken to be the unweighted average of all of the price quotations for each commodity in that city.

As Table 6 shows, the food items included in the index have been subdivided into several major groups. Where prices were missing for any commodity, it has been assumed that its price varied with the other commodities in its group, and its weight has been redistributed evenly among those commodities.

\footnotetext{
44 Coelho and Shepherd, "Differences in Regional Prices," pp. 585-86, appendix table 1.

45 These studies are reviewed in Jeffrey G. Williamson, "Consumer Behavior in the Nineteenth Century: Carroll D. Wright's Massachusetts Workers in 1875," Explorations in Entrepreneurial History, 2nd series, 4 (Winter 1967), pp. 98-135.

${ }^{46}$ Coelho and Shepherd, "Differences in Regional Prices," pp. 562-64.

47 U.S. Treasury Dept., The Costs of Labor and Subsistence.

48 The results of these surveys are reported in U.S. Dept. of Commerce and Labor, Eighteenth Annual Report, pp. 664-845, table 1.
} 
TABLE 6

COMMODITIES AND WEIGHTS USED IN CONSTRUCTING RELATIVE RETAIL FOOD PRICE INDICES

\begin{tabular}{|c|c|c|}
\hline \multirow{2}{*}{$\begin{array}{l}\text { Commodity and Major } \\
\text { Group }\end{array}$} & \multicolumn{2}{|c|}{ Weights } \\
\hline & 1869 & 1890 and 1898 \\
\hline \multicolumn{3}{|l|}{ Cereals } \\
\hline Flour, wheat (superfine) & 7.083 & 17.669 \\
\hline Flour, wheat (extra family) & 7.083 & \\
\hline Flour, rye & 2.000 & \\
\hline Corn meal & 2.000 & 2.004 \\
\hline Rice & 0.364 & 0.364 \\
\hline \multicolumn{3}{|l|}{ Meat and Fish } \\
\hline Beef, fresh roasting pieces & 4.736 & $7.808^{\mathrm{a}}$ \\
\hline Beef, fresh rump steaks & 4.736 & 7.808 \\
\hline Beef, fresh soup pieces & 1.093 & \\
\hline Beef, corned & 1.093 & 1.615 \\
\hline Pork, fresh & 2.368 & 3.500 \\
\hline Pork, corned and salted & 0.547 & \\
\hline Pork, bacon & 0.547 & 2.020 \\
\hline Pork, smoked ham & 0.547 & 2.020 \\
\hline Pork, shoulders & 0.547 & \\
\hline Pork, sausage & 0.547 & \\
\hline Veal, forequarters & 0.911 & \\
\hline Veal, hindquarters & 0.911 & \\
\hline Veal, cutlets & 0.911 & \\
\hline Mutton, forequarters & 0.911 & \\
\hline Mutton, legs & 0.911 & \\
\hline Mutton, chops & 0.911 & \\
\hline Mackeral, pickled & 1.275 & \\
\hline Codfish, dry & 1.275 & \\
\hline \multicolumn{3}{|l|}{ Dairy Products } \\
\hline Milk & 5.465 & 5.465 \\
\hline Butter & 10.747 & 10.747 \\
\hline Cheese & 0.911 & 0.911 \\
\hline \multicolumn{3}{|l|}{ Vegetables } \\
\hline Potatoes & 8.379 & 8.379 \\
\hline Beans & 4.372 & 4.372 \\
\hline \multicolumn{3}{|l|}{ Other Food } \\
\hline Eggs & 4.189 & 4.220 \\
\hline Tea & 2.368 & 2.385 \\
\hline Coffee, green & 3.643 & \\
\hline Coffee, roasted & 3.643 & 7.339 \\
\hline Lard & 2.732 & 2.752 \\
\hline Sugar & & 8.256 \\
\hline Yellow B & 2.732 & \\
\hline Yellow C & 2.732 & \\
\hline Good Brown & 2.732 & \\
\hline Molasses & & 0.367 \\
\hline New Orleans & 0.189 & \\
\hline Puerto Rico & 0.189 & \\
\hline Syrup & 0.189 & \\
\hline
\end{tabular}

a Includes stewing pieces.

Source: See the Appendix. 